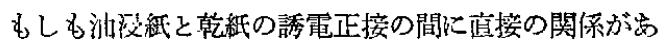
るとすれば， $110^{\circ} \mathrm{C} \sim 130^{\circ} \mathrm{C}$ の空気中で，絶縁悢を㸪 鳘することが，少化を少なくして，高温度誘電正接を 下げるのに最も部した温度であるということが性束る。

\section{IV 総括}

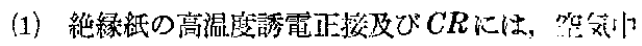

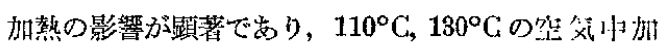

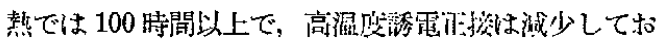

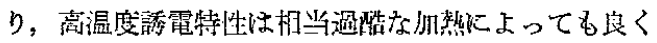
なっている。

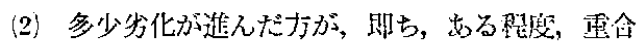

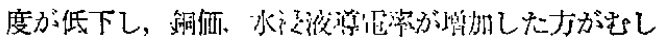

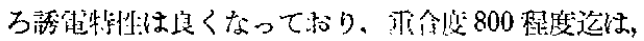

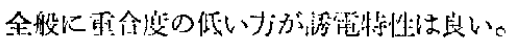

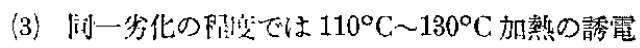

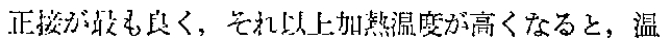

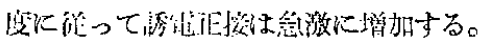

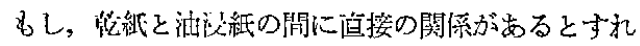

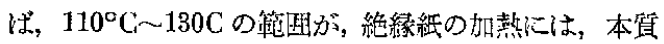
阿汇激しているというこそが出来る。

(1) カルボキシル基惊, 最初, 減少し, 相当䧟酷な 扣然を受惊心後に增加し始める。

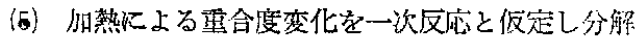
の原边速度恒数を求め，これより活性化エネルギーを 計算すると $29.6 \mathrm{kcal} / \mathrm{mol}$ の值を得た。

発麦を許可された井上社長，御指導を賜った䑬巨管

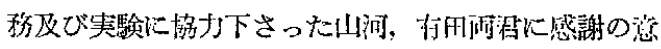
を表守る。

V 引用文献

(1) 例沈济

F. M. Clark, Elec. Eng. 54, 1088 (1935)

F. M. Clark, Trans A.I.E.E. 61, 742 (1942)

F. M. Clark Trans Electrochem Soc, 83, 143 (1943)
V. M. Montosinger Trans A.I.E.E. 49, 776 (19 30)

V. D. DelMar Trans A.I.E.E. 40, 97 (1921)

(2) 嬑椂, 山中, 日野, 電学誌 77,1610 (昭 32)

（3）苝藤，山中，日野，䉓気連合大会 341（昭 33）

(4) J. B. Whitehead and E. W. Greenfield Trans A.I.E.E. 53, 1389 (1934)

(5) F. M. Clark. Ind Eng. Chem. 44, 887 (1952)

（6）内藤，島，佐藤，日立評宿 35,1753 (昭 28)

(7) 下山田, 常松, 日立評論 36,1823 (昭 29)

（8）下山田，常松，電気連合大会講演（昭 32）

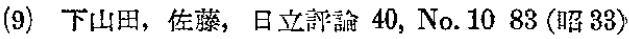

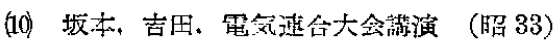

(11) 坂标材料武験 3,495 (昭 29)

(12) A. F. Martin Tappi 34, 363 (1951)

(13) H. Sobue and M. Okuho Tappi 39, 415 (19 56)

(11) A. J. Stamm : Ind Eng Chem 48, 413 (1956)

(15) Wiegerink, J. G. Tex. Res. J. 10, 357. 493 (1940)

(16) Basch R. H. U. S. Bur-Standards J. Research 7, 465 (1931)

(1in) A. Pacult and G. Saurt Compt. Rend 246 . 608 (1958)

(18) F. J. Murphy, Trans. Am Electrochem. Soc. 83,161 (1943)

(19) Perlin, A. S: Can. J. Chem. 30, 278. 290 (1952)

(20) 祖公江, 右田, セルローズハンドブック $262 \mathrm{p}$

(21) Farquhar. R. L. W., Pesant, D., and McLaren. B. A.: Can. Textile J. 73, 51 (1956)

(22) W. D. Major: Tappi 41, 530 (1958)

(23) 吉野, 工業化学雑誌 61,127 (昭 33)

(2) C. R. Calkins: Tappi 33. 278 (1950)

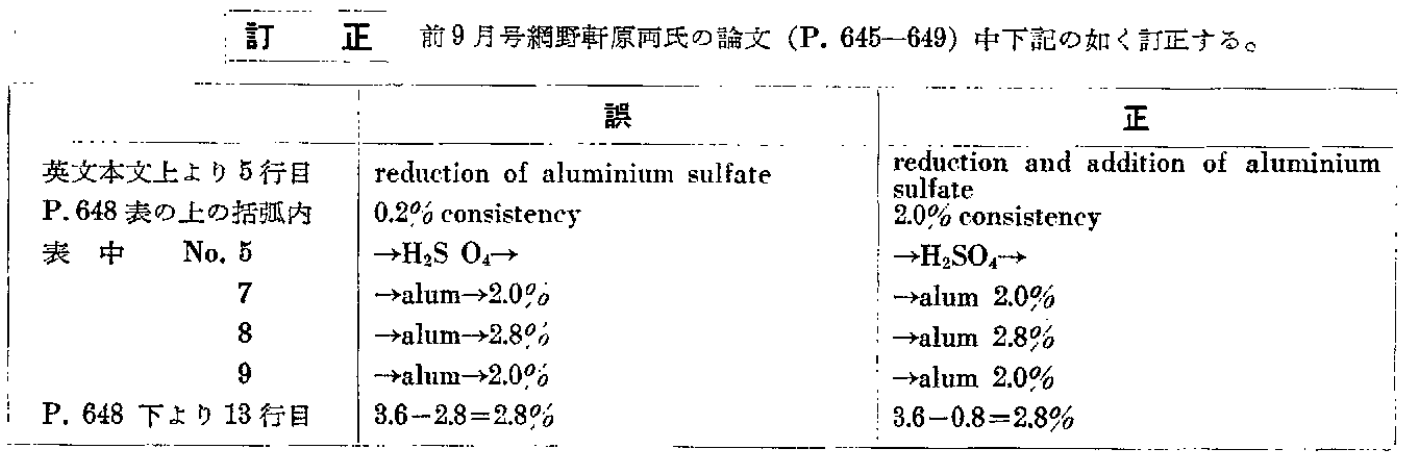

